\section{Health, development and innovation: a contribution of the critical theory of technology to the discussion}

\author{
Saúde, desenvolvimento e inovação: \\ uma contribuição da teoria crítica \\ da tecnologia ao debate
}

Salud, desarrollo e innovación: contribución

de la teoría crítica de la tecnología

para debatir
Luis Eugenio Portela Fernandes de Souza 1

\begin{abstract}
The relationships between health and socioeconomic development are diverse. These relationships find in the health economic complex a privileged ground for expression. The importance of health technologies increased exponentially since the middle of the 20th century, affecting health systems in terms of both, quality of care and economic aspects. In fact, the predominant model of care is based on fragmented, symptomatic therapy practices that encourages the use of products and services and promotes a passive participation of users rather than humanization of care. Overcoming this model requires changes in the health technology standards which, in turn, require changes in the technology standard of society. The critical theory of technology helps to understand the evolution of the industrial civilization. It enriches the discussion by suggesting the health economic complex be more sensibly adjusted to the requirements of comprehensive health care, and to inclusive and sustainable development.
\end{abstract}

Biomedical Technology; Economic Development; Sustainable Development; Innovation

$\begin{array}{ll}1 \text { Universidade Federal da } & \text { Correspondence } \\ \text { Bahia, Salvador, Brasil. } & \text { L.E.P. F. Souza } \\ & \text { Universidade Federal da } \\ & \text { Bahia. } \\ & \text { Rua Basílio da Gama s/n, } \\ & \text { Campus Universitário } \\ & \text { Canela, Salvador,BA } \\ & \text { 40140-060,Brasil. } \\ & \text { luiseugenio@ufba.br }\end{array}$


The relationships between health and socioeconomic development of a given nation are diverse and complex. First of all, in a broader sense, development is defined by the promotion of social well-being, including good health status 1 . Secondly, it is well-known that economic growth leads to improvements in health 2, and, as well, the overall good health condition of the population contributes to economic growth 3. Finally, in addition to vital status, health is an important economic sector: World Health Organization data 4 indicate that the resources invested in the health sector correspond to $9.7 \%$ of the world's Gross Domestic Product (GDP), an estimated US\$ 5.3 trillion in 2007.

These relationships in their different dimensions find in the health economic complex, which includes health services and input-manufacturing companies 5 , the privileged space for expression.

If health care is essentially based on human interaction, which includes on one hand people with healthcare needs and on the other people with specific professional skills, its practices requires, invariably, resorting to multiple technologies to support prevention, diagnosis and therapy. Thus, healthcare services and health input-manufacturing companies must be coherently articulated.

The importance of technologies has increased exponentially since the middle of the 20th century, making inconceivable, today, the delivery of quality health services without resorting to technology, most of which is quite innovative. Medical-scientific technologies have largely contributed to the health status of people: suffice to mention the advances of the invention or discovery of antiseptics, anesthetics, antibiotics, vaccines, etc. Simultaneously, health technologies have contributed to the generation of wealth and overall economic growth.

However, one should bear in mind that, at times, technologies are iatrogenic or favor later, symptomatic interventions, rather than prevention or the etiologic treatment, or even contribute to reduce the autonomy of the person using them. For instance, it has been known for a long time that nonsteroidal anti-inflammatory drugs are an important cause of upper gastrointestinal bleeding; that the use of antibiotics can lead to the proliferation of super bacteria, and that drugs for degenerative diseases such as diabetes, high blood pressure and neoplasms can make people dependent on healthcare services.

From the economic standpoint, technologies, including the most innovative ones, have markedly raised healthcare costs for both, families and service systems. In Brazil, the Institute for Supplemental Health Studies 6 calculated that, in 2012, the medical and hospital costs variation rate was $15.4 \%$, which was three times the inflation rate measured by the Broad National Consumer Price Index, with the rising costs of hospital-use materials being mainly accountable for this rise in price.

The field of Public Health has generated reflections and experiments on care 7 and on healthcare models ${ }^{8}$, but that has not been enough for more effective, efficient or humanized actions to be developed within the scope of services. On the contrary, one observes the predominance of fragmented care practices that focus on symptomatic treatments, disregard preventive approaches, stimulate the use of products, and diagnostic and therapeutic services, and promote, instead of humanization, passive and subordinate user participation.

Therefore, health systems face a huge challenge: how to overcome an often ineffective and expensive healthcare so that the goals of the two poles of the health economic complex-services and manufacturing industries - converge, to provide services and technologies that are more effective, safe, humanized and affordable to society?

In order to answer this question, initially one must look into the current model of care, that may be characterized, in short, as being biologicist and mercantilistic.

The current model of care is related, at least in part, to the economic interests of industrial and financial organizations within the industry of drugs, immunization, equipment and other medical and hospital supplies. Clearly they are powerful agents economically and politically, considering the investment they make in electoral campaigns in a number of countries, including Brazil 9.

However, the issue is more complex: it goes further than just controlling the excesses of the pharmaceutical industry or nationalizing input production. Ultimately, the healthcare model reflects the standard of technology of contemporary society. Not only in healthcare delivery, but in all aspects of social life, a given social-technical standard became predominant. Just think about the preference for cars as a mean of transportation 10 or the intensive use of pesticides 11 .

To understand how this scenario was reached and how to overcome it, one should consider the reflection of American philosopher Andrew Feenberg 12, who revisits two major theoretical approaches on technologies - the instrumental and the substantive theories - and proposes a third one.

The instrumental theory conceives technologies as being neutral from the point of view of 
ethical values and social interest, and as being controlled by human beings in regard to their development and use. This is the hegemonic conception according to common sense. It is expressed when one says, for instance, that guns do not kill people, but it is people who kill people (which is half-true, as there would be no gun manufacturing if there were no purpose of killing). Therefore, the creation and evolution of technologies would be the result of technical options made by inventors about their operating mechanisms.

Technology's neutrality has, at least, four aspects 13: (a) technology, as sheer instrumentality, is indifferent to the purposes of its use; (b) it is also indifferent to politics, and can be used in any social setting; (c) neutrality is due to the "rational" character of technology, i.e., the scientific, causal propositions it is based on maintain their cognitive conceptual status under any circumstances; and (d) technology is neutral as it complies with the safe efficiency rule regardless of the setting it is placed in.

Interpreting the position of Feenberg, Neder 14 characterizes the instrumental theory as the modern optimistic vision of technology based on a liberal faith: a single trajectory of progress, and growing knowledge.

The substantive theory, in contrast, states that technologies reflect ethical values and are shaped by social interests, but are not controlled by human beings, in the sense that their use and development are due only to improvements in efficiency as the logic intrinsic to the technique. Despite deviating from common sense, this conception has advocates as prominent as Martin Heidegger, who highlights the fact that social relations are structured with the use of technology, particularly in modern society, to the point of causing irreversible dehumanization of society.

Like Heidegger, Jacques Ellul considers technology as a new cultural system that structures the entire social world as an object of control 15 . Technology would have become the defining feature of all modern societies, regardless of political ideologies. The technique has become autonomous, according to Ellul 13.

The substantive theory makes evident that, by deciding on the use of technology, societies are making commitments without actually pondering on the type of life they wish. One example 13 is the impact of the proliferation of fastfood restaurants on family relations, as lunch and dinner used to be occasions for all family members to gather, pivotal for the creation and maintenance of ties.

Despite being so different, the instrumental and the substantive theories have in common an attitude Feenberg 13 calls "technology, take it or leave it". On one hand, as mere instrumentality and indifferent to values, technology is not an issue of public debate; only the effectiveness of its application can be discussed. In this case, it should be embraced and enhanced. On the other hand, as a vehicle of a culture of domination, technology advances to consolidate social dystopias. In this second instance, it should be rejected for the sake of preserving humanism. However, in none of these cases can technology be transformed.

Feenberg 12 identifies himself with the substantive theory when he considers that technologies, in fact, are not neutral in terms of values and interests, but are permeated by social relations and express ethical options and social purposes. On the other hand, he shares with the instrumental theory the idea that technological development is guided by conscious human action, and the striving for efficiency and any other logic inherent to its operation are under control of human beings.

The American philosopher adopts, then, a third point of view, one that explains how the currently dominating technology is designed to serve capitalists interests, even though it has value for use, and how can it be designed differently to adapt to the needs of a free society.

Rejecting the neutrality advocated by the instrumental theory, and the substantive theory's fatalism, the author considers that the dominant form of technological rationality is not an ideology, the discursive expression of class interests, or the neutral reflex of natural laws. It is, instead, a rationality shaped in the intersection between ideology and technique articulated to control people and resources.

As Dias \& Dagnino 16 highlight, Feenberg's critical theory acknowledges the de-humanizing consequences of technological development evidenced by the substantive theory; rather, it believes in the possibility of another type of technological development. For it, the core problem is not related to technological advances per se, but their control according to the values and interests of dominating social groups. Thus, the democratization of the decision process about technology creation, development and production is at the base of the construction of an alternative model of society.

Feenberg bases himself on Marcuse 17 who denounces the totalitarian character of both, Western capitalism and the Soviet communism, basically due to scientific and technological advances, and on Foucault 18 who analyses the relations between knowledge and power, showing that in modern societies, new knowledge and new technologies enhance the disciplinary po- 
wer everyone is subjected to, to affirm that rationality integrates a system of domination, even though it is cognitively successful. He argues that the type of rationality that is prevalent in capitalism has two roles: it favors the hegemony of the dominating class' beliefs and practices while maintaining some ability to produce knowledge about reality. The social and technical requirements of capitalism - the development of productive forces and the maintenance of the current production social relations - are condensed in a rationality that leads to the construction of technical systems according to the requirements of the dominating system. This phenomenon is named by Feenberg social code of technology or technical code. The technical code disposes values and interests according to rules and procedures, devices and artifacts.

Individual technologies are developed with technical elements combined in a given way to meet certain social purposes, which are, therefore, incorporated in devices and artifacts. Or, as Latour 19 would say, each technology draws together a "sociogram" of alliances of social interests around a specific "technogram", i.e., a specific configuration of technical elements. In this sense, the technical code of capitalism may be defined as the general correlation rule betwee the "sociogram" and the "technogram".

According to Feenberg 13, new technical codes can be developed and, once disseminated, may become the basis of the new industrial civilization, overcoming capitalist economic values and interests, and promoting those of environmental preservation, social equality and human development. Worthy of note is that the new technical codes may be developed from the existing technology, using their ambiguities and fulfilling their potentialities repressed by work exploitation and alienation.

An example Feenberg presents 12,13 of the use of ambiguities and potentialities relates to the computer and the Internet. He recalls that the computer (both the hardware and the software) was created as a device to calculate and to store information, not for communication. The function of communication had not been foreseen by the early inventors; however, it was potentially contained in its technical codes which, once rearranged, turned the computer, with the Internet, into a means of communication. It is important to add that technical recoding was instigated by "lay" users, not IT experts.

Another computer- and Internet-related example is online education. Feenberg considers that, in this case, the technological design is still pending between two conceptions: (a) the automation of education, meaning an attempt to make educational practices cheaper for business leaders, as contents designed by a knowledgeable professor are replicated by many less-prepared and poorly-paid tutors to a larger set of students who merely receive the contents; and (b) computerization of education, meaning the attempt to preserve the professor-student personal interaction and the fundamental teachinglearning process base despite the mediation of equipment. These two conceptions are influencing the development of technical codes that constitute the computer network, and even if one of these becomes hegemonic, ambiguities will remain.

Finally, as Dagnino 20 highlights, the critical theory of technology suggests that this is not about being for or against technology, in line with the instrumental and substantive theories, but to democratically discuss and decide what values or purposes should guide the development of technology, and how the technical elements may be combined to promote these values and reach these purposes.

On reflecting upon the relations between health, development and innovation, the critical theory brings to mind the following questions: what values and interests have guided the development of health technologies? What values and interests are incorporated into the current technologies?

The results of studies led by Pascale Lehoux, a Canadian public health researcher, help in responding to these questions 21,22,23,24.

Initially, Lehoux 21 highlights that health technology derives from the confluence of two opposing dynamics, the constant flow of innovation and the budgetary limitations of healthcare services. From this confluence the field of health technology assessment (HTA) has emerged, whose rationale is based in differentiating "good" and "bad" innovations, and in the selection of the former, which are, basically, those that are more cost-effective than previously existing technologies.

Even though initiatives such as HTA are intended to strengthen the technical-economic rationale of the decision-making process so that the technologies incorporated into the health system are useful and valid, Lehoux considers more important to examine, first, the process of technology innovation and production. She states that the options made at the initial moment of innovation development will determine the cost of technology, the types of use and the skills required to manage it.

She then maps out those that are involved in health innovation processes. Upon analysis of the Canadian case 21,22,23, she identifies three big 
players - industry, university and government - amongst whom there are intricate relations and flow of resources. Industry includes the big pharmaceutical industry as well as medium- or small-size companies that manufacture equipment or other health-service inputs. Universities are represented particularly by medical investigators who work in the most prestigious university hospitals. Government refers to highranked officials of health-related, and research and innovation bodies at federal and provincial levels. In addition to these three more powerful players, health professionals in general, associations of patients of different diseases, other civil society organizations and media professional also take part, however less significantly, in the innovation processes.

These empirical studies make evident a somewhat constant decision-making pattern about the investment in health technologies. In general, the big players try to identify the needs and possibilities of new technologies, or improvements in existing technologies by imagining what could be of interest for technology users (medical practitioners in particular, but also patients), and estimating the prices they would be willing to pay to have access to a new technology. That is how the business models of investmentdeserving health technology development projects are designed, driving the efforts of innovation according to the expectations of investors 23 . Interestingly, even the influence of medicalscientific knowledge 24 is secondary to the commercial and financial interests in the designing of technologies. Similarly, the involvement of users is somewhat disregarded 22 .

In short, there are two core criteria of the decision-making process regarding the investment in the development of new technologies, desirability and affordability, according to the Canadian professor. These criteria are clearly in accordance with the logic of the market.

The health industry worldwide is structured as an oligopoly, with few large organizations controlling the market, and competition is largely based in the generation of innovations. Therefore, the pressure of economic interests for the production of novel technologies is huge, and explains the significant investments in research and technological development.

Therefore, it is easy to realize that the capitalist economic logic has strongly determined the course of technological development also in the healthcare area. Thus, one can state that, basically, the interests and values of big health-related organizations are incorporated in medical and hospital inputs, and that drive the development of new technologies.
The predominance of the commercial logic is a problem for all (including shareholders of the companies, as they also need healthcare services), because the process of innovation subjects all other values to competitiveness, which has enhanced the negative effects of technologies: iatrogenicity, user dependence, raising the costs of health system, and medical practice dehumanization. Why, then, does it remain predominant?

The obvious response lies in the economic power of the health industry, able to convince the public through marketing strategies, and also health practitioners, the media, congress representatives, government officials, etc. with the use of diverse and effective strategies.

However, the less obvious but more relevant response is that there is actual and symbolic effectiveness in the current technologies. In fact, how is it possible to deny that intestinal-bleed causing anti-inflammatory drugs do control inflammations? Or how can one deny that fetal sonographies also represent pictures of the baby, and are seen with tenderness and affection?

At a closer look, one can see that it is the mention of the effectiveness of some technologies that make the persuasive strategies used by the health industry effective. However, one must bear in mind that it is a typical marketing strategy to (improperly) expand the successes achieved in some cases to all the cases, and of some technologies to all technologies.

What the critical theory of technology allows to understand is that such effectiveness, whether concrete or symbolic, may be limited and restrained by economic interests. There are potentialities in current technologies that are not made real; they are repressed to prevail the commercial interests, legitimated by the search of efficiency, defined in a very narrow way. Just like computers that had a technical bias against their use as a communication tool among people, but had the potential to be redesigned for such purpose 13 , health technologies have their technical codes favoring business interests, but they may be redefined to meet the needs of public health.

The critical theory of technology and the empirical findings of the investigations by the Canadian group prompted the questioning as to what extent the production of health technologies focused on symptoms rather than on etiology is due to the current state of the art of scientific knowledge or is basically driven by the pursuit of profit. Or to what extent the lack of investment in health-promotion technologies is a consequence of difficulties in the private appropriation of investments made in public assets, as those related to the social determinants of health, rather than epistemological obstacles. 
Considering that the current health technologies and the current innovation processes are limited by capitalist interests, the challenges that are posed are how to free the technological development from the bonds imposed by commercial purposes, and how to take advantage of the potentialities of technology to make them safer, more humane and more cost-effective.

Adopting a public health perspective, Lehoux et al. 25 indicate three attributes that should be sought by new health technologies: relevance, usability and sustainability. Relevance relates to health problems the technology is intended to solve: if they are, indeed, those considered a priority by health policies. Usability relates to ease of use, this means, less need of complex skills or resorting to specialists to use the technology. Finally, sustainability addresses the impact of the incorporation of technology on the maintenance of health systems; in other words, it deals with the development of technologies whose costs still make long-term financing of health systems feasible.

To favor the search of these attributes, the Canadian authors believe it is essential to expand social participation in the innovation processes 22 . However, they note that public involvement requires the dichotomy between the "objective" scientific knowledge and the "normative" common sense be overcome. In fact, both types of knowledge are intrinsically related; therefore, social participation initiatives must reinforce deliberative processes that maximize the mutual learning of various groups of scientists and non-scientists.

Ultimately, the first and foremost strategy is to expand the community of designers 21 , who are the individuals and groups involved in the decisions about lines of research and technological development that deserve funding.

In the case of health technologies, in addition to well-reputed medical practitioners, pharmacists, nurses, engineers, economists, market analysts, officials and experts of research and innovation agencies, it is necessary to involve among decision-makers the users, the clients and the citizens, through representatives of society, including those whose health issues are not among their main daily concerns.

It is noteworth that is in line with the fact that, typically, technologies derive from publicly funded research studies; the destination of resources that come from the whole of society should and can be defined with the participation not only of experts, but also of taxpayers and citizens.

A decision-making community thus expanded may sanction the epidemiological profile of the entire population, not only of those who can afford them, as a starting point, and drive the investments towards the production of knowledge and the development of technologies targeting the most prevalent, or most debilitating, or most lethal health problems.

It can also consider health in its positive dimension, and not only the disease as the target of technologies; that is, one can think about the development of health promotion and protection technologies, in addition to those that target health recovery or rehabilitation.

This second strategy to promote a technological development better suited to healthcare needs and less limited by economic interests includes a number of measures to limit the power of the big health industry. Professor Marcia Angell 26 suggests (a) demanding that innovations add, in fact, something useful, putting an end to imitations; (b) not allowing pharmaceutical labs to control clinical trials, but rather that these be conducted by independent investigators; (c) reduce the term of patent validity, which should be counted from the time the drug is marketed; (d) prevent the participation of the health industry in the education of drug-prescribing health practitioners; (e) forbid advertisements directly targeting the consumers; and (f) control the prices of the technologies, by having the company's black accounting books open, which is feasible considering that the government is the largest procurer.

The second strategy is apparently feasible without structural changes in society; the first one, however, requires significant social transformation. Or, more specifically, for the expansion of the designers' community to occur and favor humanistic-driven technological development, three major changes in the social order are required, as Feenberg points out ${ }^{13}$ : socialization of the means of production by expanding government actions in planning, in face of the market; the strengthening of democracy with significant reduction of social inequalities; and the adoption of a model of innovation intended to overcome the separation between manual and intellectual labor, by expanding and intensifying continuing education.

Typically, socialization means nationalization or state control of private productive resources. In this case, it is a political-administrative change that, despite its large-scale, is unable, by itself, to change society. As seen by Feenberg, socialization of the means of production requires the design of new technical codes. Just as the abolishment of child labor has allowed the "invention" of modern childhood 12 , the new technical-economic codes will allow the emergence of a socialist society. More than the control of the 
industry by the state, it will be the knowledge and skills of workers, and the democratic participation that will allow the definition of new technical codes for the emergence of socialism. According to his perspective, socialism does not emerge at once, with the coming to power of a proletarian-representative party, but gradually, from the transformation of the social code of technology, made possible by the extension of democracy up to the core of the productive forces development process.

The transition for this higher type of industrial society involves a radical change in economic culture: wealth, in capitalist society, is expressed by merchandise, while in a socialist society, the actual wealth is the full development of human abilities mediated by material goods, but not the goods themselves. A socialist society values the expansion of the human experience and individuality as an end in itself 13 . Of note is that this expression by Feenberg is unequivocally close of the expanded idea of development as fosterer of well-being, including good health conditions 1 .

The strengthening of democracy with the significant reduction of social inequalities implies, according to Feenberg, the democratization of technologically-mediated institutions. The management power should be shared with the workers, who do not need to be experts, but who should have the abilities to understand the entire work process in which they are involved developed. Thus, education is essential for democratization. The socialization of the means of production should include the socialization of the cultural capital beyond the machines, the buildings, the land, and encompass the skills and knowledge required for the management of the industry. Therefore, self-management practices can be consolidated and disseminated, initially at workplaces, and later to other spheres of activities, such as urban planning and healthcare 13 . In a socialist society, education would no longer be an investment needed to prepare the worker to perform certain activities but would become a driving force for social and technological change.

Eventually, the educational advancement would raise the level of labor productivity, with the introduction of new technologies and new methods of work adapted to a highly educated workforce. Thus, education is also a driving force for socialist values-driven innovation. Indeed, well-educated workers working in democratically managed institutions would be in better conditions to contribute to the development of innovations based on technical codes that no longer aim at profit maximization and workforce control, but at the promotion of well-being and preservation of the environment. Workers who are educated and have power over the organization of the work process are capable to overcome the separation between manual and intellectual labor. Feenberg 13 anticipates the objection that the State suppresses the individual freedom necessary to the innovation process by saying the idea of an isolated genius inventor is a myth, and that the qualified participation of all workers in the management of technologically-mediated organizations does not limit, but rather promotes the freedom of everyone.

These structural changes, if they ever come through, will be the consequence of, on one hand, the accumulation of experiences of definition of new technical codes, and on the other, the mobilization and participation of citizens. The distress that seems to assail contemporary civilization, caused by an increase in violence, inequalities, and the poverty of many in favor of material wealth of fewer and fewer people, even in the world's more developed countries, can nurture this mobilization and trigger major transformations.

Feenberg proposes a new industrial civilization. In the healthcare area, this means a reconfiguration of the health economic complex, driving it towards the production and use of novel technologies and services that are more effective, safe and cheap, and can, at the same time, improve the health status of individuals and the population as a whole, and contribute to inclusive and sustainable development. In the short or medium term, the reorientation of the economic complex may be favored by the adoption of measures suggested by Angell 26, but it is likely that its radical reconfiguration will depend on the structural changes pointed out by Feenberg.

Finally, it is worth mentioning that the purpose of social transformation is not foreign to the Brazilian Public Health Reform Project, with the inclusion in the Brazilian Constitution of the right of all to health, whose enforcement requires the development of social and economic policies to ensure life conditions that promote well-being. 


\section{Acknowledgments}

I thank the two anonymous reviewers for their criticisms and suggestions.

\section{References}

1. Stiglitz J, Sen A, Fitoussi JP. Report by the Commission on the Measurement of Economic: performance and social progress. http://www.insee.fr/ fr/publications-et-services/dossiers_web/stiglitz/ doc-commission/RAPPORT_anglais.pdf (accessed on 22/Feb/2015).

2. Albuquerque E, Cassiolato J. As especificidades do sistema de inovação do setor saúde. Revista de Economia Política 2002; 22:134-51.

3. World Bank. World Development Report 1993: investing in health. Oxford: Oxford University; 1993.

4. World Health Organization. World Health Statistics 2012. Geneva: World Health Organization; 2012.

5. Gadelha CAG. Desenvolvimento, complexo industrial da saúde e política industrial. Rev Saúde Pública 2006; 40(n.spe):11-23.

6. Instituto de Estudos de Saúde Suplementar. Índice de variação de custos médico-hospitalares - VCMH/IESS. Data-base: dezembro de 2012. http://www.iess.org.br/html/VCMHIESSdbdez12. pdf (accessed on Jun/2015).

7. Silva-Júnior AG, Merhy EE, Carvalho LC. Refletindo sobre o ato de cuidar da saúde. In: Pinheiro R, Mattos R, Camargo Jr. KR, organizadores. Construção da integralidade: cotidiano, saberes e práticas em saúde. Rio de Janeiro: Instituto de Medicina Social, Universidade do Estado do Rio de Janeiro/ Abrasco; 2003. p. 113-28.

8. Teixeira CF, Solla JP. Modelo de atenção à saúde: vigilância e saúde da família. Salvador: EDUFBA; 2006.

9. Eller G, Cardoso L. O financiamento de campanhas políticas pelas indústrias farmacêuticas brasileiras: saiba como funcionam as estruturas que envolvem as indústrias farmacêuticas e os seus investimentos. http://jpress.jornalismojunior.com. br/2014/10/financiamento-campanhas-politicasindustrias-farmaceuticas-brasileiras/ (accessed on 24/Feb/2015).

10. Mano MK. O automóvel ainda é prioridade. Desafios do Desenvolvimento 2011; 8:33-9.

11. Associação Brasileira de Saúde Coletiva. Dossiê Abrasco: um alerta sobre os impactos dos agrotóxicos na saúde. Parte 1 - agrotóxicos, segurança alimentar e saúde. Rio de Janeiro: Abrasco; 2012.

12. Feenberg A. Between reason and experience: essays in technology and modernity. Cambridge: MIT Press; 2010.

13. Feenberg A. Transforming technology: a critical theory revised. 2nd Ed. Oxford: Oxford University Press; 2002.

14. Neder RT. Andrew Feenberg: racionalização democrática, poder e tecnologia. Brasília: Observatório do Movimento pela Tecnologia Social na América Latina/Centro de Desenvolvimento Sustentável, Universidade de Brasília/Coordenação de Aperfeiçoamento de Pessoal de Nível Superior; 2010. (Série Cadernos - Primeira Versão, 21752478; 3).

15. Latouche S. Jacques Ellul contre le totalitarisme technicien. Neuvy-en-Champagne: Éditions le Passager Clandestine; 2013.

16. Dias R, Dagnino R. A política científica e tecnológica brasileira: três enfoques teóricos, três projetos políticos. Revista de Economia 2007; 33:91-113. 
17. Marcuse H. A ideologia da sociedade industrial. $6 a$ Ed. Rio de Janeiro: Jorge Zahar Editor; 1979.

18. Foucault M. Vigiar e punir: nascimento da prisão. 28ạ Ed. Petrópolis: Editora Vozes; 2004.

19. Latour B. La science en action. Paris: Gallimard; 1995.

20. Dagnino R. Neutralidade científica e determinismo tecnológico: um debate sobre a tecnociência. Campinas: Editora da Unicamp; 2008.

21. Lehoux P. The problem of health technology. Its policy implications for modern health care systems. New York: Routledge; 2006.

22. Lehoux P, Daudelin G, Demers-Payette O, Boivin A. Fostering deliberations about health innovation: what do we want to know from publics? Soc Sci Med 2009; 68:2002-9.

23. Lehoux P, Daudelin G, Williams-Jones B, Denis J-L, Longoe C. How do business model and health technology design influence each other? Insights from a longitudinal case study of three academic spin-offs. Res Policy 2014; 43:1025-38.

\section{Resumo}

As relações entre a saúde e o desenvolvimento socioeconômico são múltiplas. Essas relações têm o complexo econômico da saúde como o espaço privilegiado de sua expressão. A importância das tecnologias de saúde aumentou exponencialmente desde meados do século $X X$, com efeitos sobre os sistemas de saúde, tanto em qualidade da atenção, quanto em aspectos econômicos. Na realidade, predomina um modelo de atenção caracterizado por práticas fragmentadas, que enfatizam tratamentos sintomáticos, estimulam o consumismo de produtos e serviços e promovem, ao invés da humanização, uma participação passiva dos usuários. A superação desse modelo passa pela mudança do padrão tecnológico da saúde, que, por sua vez, exige a transformação do padrão tecnológico da sociedade. A teoria crítica da tecnologia ajuda a compreender a evolução da civilização industrial. Enriquece o debate, sugerindo uma conformação do complexo econômico da saúde mais sensível às exigências da atenção integral à saúde e do desenvolvimento inclusivo e sustentável.

Tecnologia Biomédica; Desenvolvimento Econômico; Desenvolvimento Sustentável; Inovação
24. Lehoux P, Miller F, Hivon M, Demers-Payette O, Urbach $\mathrm{D}$. Clinicians as health technology designers: two contrasting tales about user involvement in innovation development. Health Policy Technol 2013; 2:122-30.

25. Lehoux P, Willian-Jones B, Miller F, Urbach D, Tailliez S. What leads to better health care innovation? Arguments for an integrated policy-oriented research agenda. J Health Serv Res Policy 2008; 13:251-4.

26. Angell M. A verdade sobre os laboratórios farmacêuticos. Rio de Janeiro/São Paulo: Edições Record; 2007.

\section{Resumen}

Las relaciones entre la salud y el desarrollo socioeconómico son múltiples. Estas relaciones tienen el complejo económico de la salud como el espacio privilegiado de su expresión. La importancia de las tecnologías de salud aumentó exponencialmente desde mediados del siglo XX, con efectos sobre los sistemas de salud, tanto en la calidad de la atención, como en aspectos económicos. En realidad, predomina un modelo de atención caracterizado por prácticas fragmentadas, que enfatizan tratamientos sintomáticos, estimulan el consumismo de productos y servicios, y promueven, en vez de la humanización, una participación pasiva de los usuarios. La superación de ese modelo pasa por el cambio del padrón tecnológico de la salud, que, a su vez, exige la transformación del padrón tecnológico de la sociedad. La teoría crítica de la tecnología ayuda a comprender la evolución de la civilización industrial. Enriquece el debate, sugiriendo una conformación del complejo económico de la salud más sensible a las exigencias de la atención integral a la salud y del desarrollo inclusivo y sostenible.

Tecnología Biomédica; Desarrollo Económico; Desarollo Sostenible; Innovación
Submitted on $25 / \mathrm{Feb} / 2015$

Final version resubmitted on $02 / \mathrm{Jul} / 2015$

Approved on 08/Sep/2015 